\title{
ページ情報エージェントの組織化による Web検索エンジンの適応インタフェース
}

\section{Adaptive User Interface of a Web Search Engine by Organizing Page Information Agents}

\author{
山田 誠二 \\ 東京工業大学大学院総合理工学研究科知能システム科学専攻 \\ CISS, IGSSE, Tokyo Institute of Technology \\ yamada@ymd.dis.titech.ac.jp, http://www.ymd.dis.titech.ac.jp/ \\ 村瀬 文彦 \\ (同上) \\ Fumihiko Murase \\ murase@ymd.dis.titech.ac.jp, http://www.ymd.dis.titech.ac.jp/
}

keywords: page information agent, the WWW, adaptive interface, a search engine, organization

\section{Summary}

In this paper, we develop an organization method of page information agents for adaptive interface between a user and a Web search engine. Though a Web search engine indicates a hit list of Web pages to user's query using a large database, they includes many useless ones. Thus a user has to select useful Web pages from them with page information indicated on the hit list, and actually fetch the Web page for investigating the relevance. Unfortunately, since the page information on a hit list is neither sufficient nor necessary for a user, the adequate information is necessary for valid selection. However which information is adequate depends on a user and a task. Hence we propose adaptive interface AOAI in which different page information agents are organized through man-machine interaction. In AOAl, the page information agents indicating different page information on a hit list like the file-size, network traffic and a page title are prepared at first. A user evaluates them through searching with a search engine, and the agents are organized based on the evaluation. As results, different organizations are achieved depending on a user and a task. Finally we make experiments with subjects and find out AOAl is promising for adaptive interface between a user and a search engine.

\section{1.はじめに}

インターネット，特にWWW の急速な広がりに伴い， 乥こから得られる情報も膨大になっている．しかし，一 般的にユーザは，自分の欲しい情報をもつ Web ページ の所在がわからないため, 検索エンジンにクェリを入力 して , 適合した Web ゚゚ージのリストであるヒットリス トを返してもらい，乥こに載っているページから欲しい ページを探すという作業を日常的に行っている．図 1 に， 主要な検索エンジンの一つである Infoseek ${ }^{* 1}$ が提示する ヒットリスト (クエリは, interface agent) の一部を示 す. 図のように,一般にヒットリストは, 単語の出現頻 度などにより計算される，クエリに対する Web ページ の適合度を基に Web ページをランキングして表示する . よって , 本来なら , ユーザは , ランキングの順にヒット リスト中の Web ページを調べていくことにより，効率 よく所望の Web ページを見つけることができるはずで ある．しかし，正確な適合度の算出は難しいため，ヒッ

*1 http://infoseek.go.com/
トリストのランキングも正確でない場合が多い.よって， 実際に欲しいページを探すには, ユーザはヒットリスト 中の Web ページを自分の判断による優先順位で調べて いくことになり，兴のときの判断材料になるのが，ヒッ トリスト中に提示されている Web ページに関する情報 (我々は，これをページ情報と呼ぶ．) である．このペー ジ情報は, 検索エンジンにより異なるが, 量的に必要十 分でもなく，被覆率と鮮度のトレードオフ [Menczer 99] により，質的に新鮮でもない場合が多い．また，さらに 重要な問題は, 適切なページ情報は, ユーザ及びタスク に依存すると考えられるため, ユーザに独立な固定した ページ情報を事前に用意できないことである．

よって, 本研究では, 検索エンジンのページ情報を個 別に表示するページ情報エージェントが , ユーザとのイ ンタラクションを通してグループ化/分解することによ り, 漸進的に適切なページ情報を提示していく適応イン タフェースAOAI (Agent Organiation-based Adaptive Interface) を提案する. AOAIでは, まず最初にページ 情報の要素を個別に表示する複数のページ情報エージェ 


\section{Agent Info}

My research concerns the use of autonomous agents in the fields of $\mathrm{HCl}$ and CSCW - commonly referred to as I nterface Agents. As such, I have collected quite a substantial bibliography on this topic as well as on ...

Relevance: 100\% Date: 26 Oct 1995, Size 2.2K, http:/ / www.cs.bham.ac.uk/ amw/ agents/ index.html Find similar pages | Translate this page

\section{IJ CAI-97 Workshop}

What the Workshop is About Workshop Committee Publication of Workshop Papers Workshop Schedule Workshop Participation I mportant Dates F inancial Support for IJ CAI-97 Participants Workshop Participants ...

Relevance: 100\% Date: 15 Oct 1999, Size 23.9K, http:/ / www.dfki.uni-sb.de/ imedia/ workshops/ anina.html Find similar pages | More results from www.dfki.uni-sb.de | Translate this page

図 1 Infoseek のヒットリスト (一部)

ントを提示して , ユーザは光れらのエージェントの示す 情報を選択的に参照しながら，ヒットリスト中のページ を調べるということを繰り返す．そとして，任意の時点で， ユーザは欲しい Web ページの選択に有効であったページ 情報ェージェントを評価し，さらにェージェントのキャ ラクタをドラッグ\&ドロップすることによりェージェン 卜の配置も自由に変更できる. 評価が高く近傍にある複 数のエージェントが新たな一つのエージェントに統合さ れ，評価の低いェージェントが消滅していくことにより， 適切なページ情報だけがユーザやタスクに応じて残って いき，適応的インタフェース [Norcio 89] が実現される

適応インタフェースの研究は, ユーザの操作履歴から ユーザモデルを構築して光れを基にユーザの次の行動を 予測し，提示するものが多い [Cypher 91, Thomas 93, Masui 94] . また , Web のブラウジングでも , ユーザの 次に見るWeb ページを予測し，提示するシステムが研究 されている [Lieberman 95, Joachims 97] .これらの適 応インタフェースシステムに対し, 本研究の目的は, コ マンド入カ , Web ブラウジングなどのシーケンシャルな 動作の予測を行うことではなく，ユーザが検索エンジン のヒットリスト中から適合 Web ページを選択するため に適切な情報を提示するインタフェースを構築するとい うことであり，大きく異なる．

Pnadit と Kalbag は, 複数認識エージェントを統合す ることにより，PC 上でのテキスト処理を支援するシス

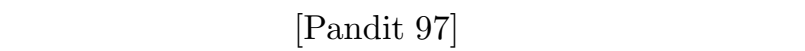
卜は,クリップボードにあるテキストから URL , 電話番 号 , 地名などの情報を獲得し, ユーザのシステムへの入 力を支援する . 複数のエージェントがテキスト情報を獲 得し, 提示する場合, 乥れらのエージェントは階層化さ れたメニューに統合される.しかし，光の統合は固定さ れており，ユーザの選好に適応できない．

Dryer は，2 つの異なるインタフェースエージェント： Wizards，Guides をいかに組み合わせるかについて報告 している [Dryer 97] . Wizards は, シーケンシャルな手 続きを正確に誘導するのに適しており，また，Guides は より柔軟性をもつ手続きを誘導できるが，しばしば誤つ た誘導を行う.本研究て我々が扱うページ情報エージェン 卜は乥れら異種の 2 つのエージェントとは異なり，ペー
ジ情報を扱うという機能レベルでは同種であり，提示す るページ情報が異なるだけである．また，エージェント の組織化の目的も大きく異なる .

Khme は，ユーザモデルに透過性を持たせ ，ユーザ自 身が弚れを修正することも許すというように，ユーザの適 応をシステムが支援する, ユーザ中心の適応インタフェー

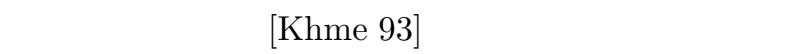
プロファイルやユーザモデルを持たないという点におい て , ユーザ中心の考えに弚うものである .

\section{AOAIによる検索}

\section{$2 \cdot 1$ ユーザインタフェース}

AOAI のユーザインタフェースであるユーザインタフ ェースウインドウUIW を図 2 に示す .このウインドウ は, ページ情報ェージェント，Web ページ番号アイコン (図 2 の $(\mathrm{A})$ ) ), 解体工場アイコン (図 2 の $(\mathrm{B})$ ) , ゴミ箱 アイコン (図 2 の $(\mathrm{C})$ ) , Exit , NextPage, BackPage ボタン (図 2 の (D)) からなる.Web ページ番号アイ コンは, Web ページを表し , マウスカーソルを弚の上に 持っていくと，すべてのページ情報ェージェントが炎の Web ページのページ情報について各自の担当する情報を 表示する.なお，この表示方法では，すべてのWeb ゚゚ー ジのページ情報を一覧することができない．しかし，数 十以上のエージェントを一度に提示して一覧表示にする と, 非常に見にくいものとなるのと, ドラッグ\&ドロッ プによる配置が困難になるなどの理由から，このような ページ毎の表示方法を用いた .

また，Web ページ番号アイコンの横にあるチェック欄 は，光の Web ページのページ情報がすべて集められた 時点でチェックされる．また，後述するように，統合さ れたエージェントの分解を解体工場アイコンで行い, 評 価により消滅したエージェントはゴミ箱アイコンに格納 されている.Exit, NextPage, BackPage ボタンは, 光

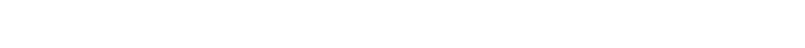
ヒットリストページの表示を行う.

\section{$2 \cdot 2$ 全体の手続き}

AOAI は, 图 3 で示すように, 検索エンジンとユーザ の間で働く適応インタフェースである.AOAI は, ユーザ 


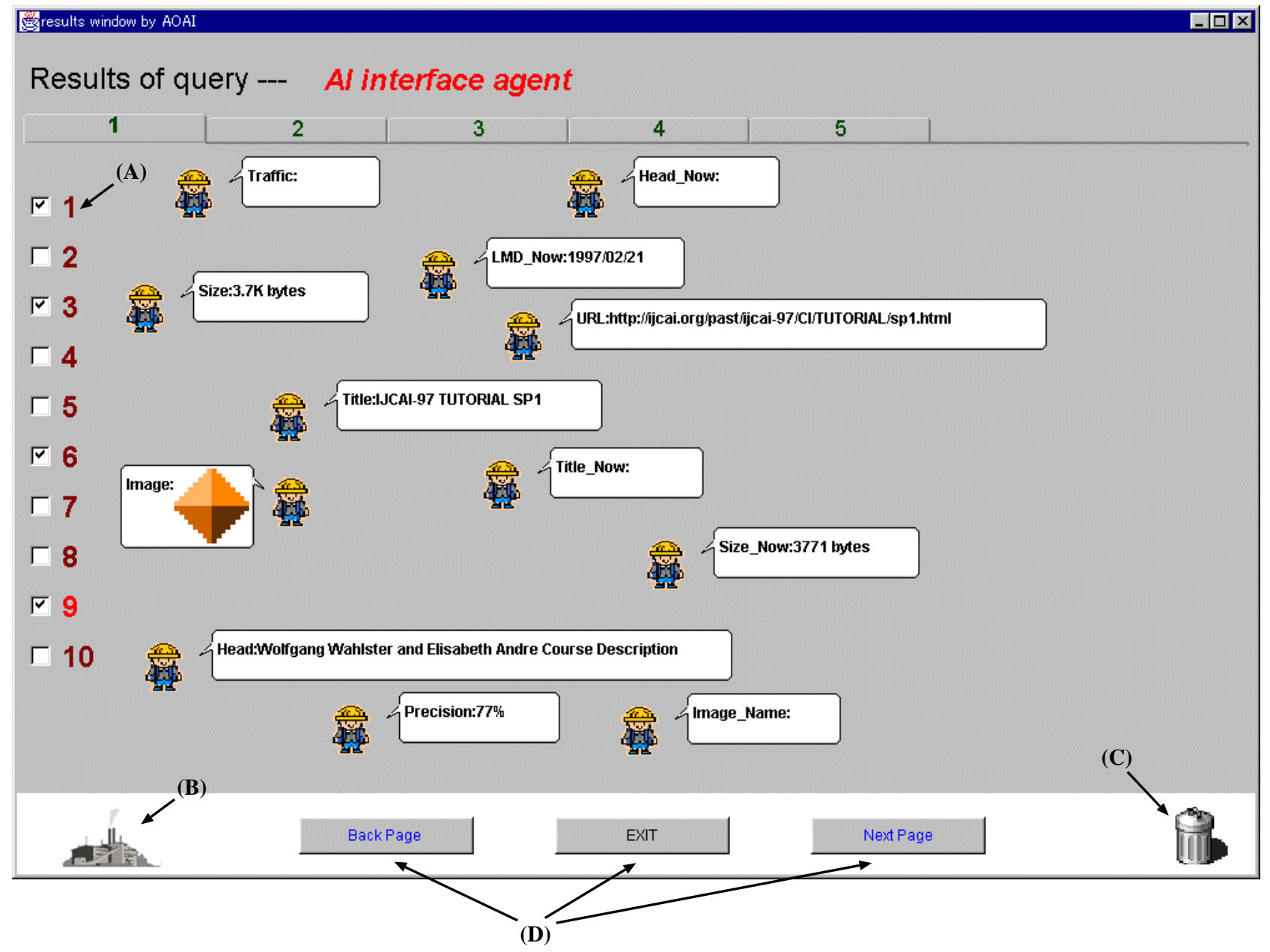

図 2 AOAI の UIW

からクエリを受け取り，光れを検索エンジンに渡し，乥 の検索結果であるヒットリストを獲得する．次に，ヒッ トリスト中に提示された Web ページのオフライン情報 とオンライン情報をページ情報ェージェントが獲得し，

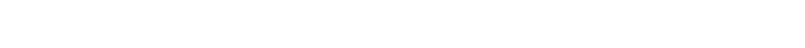
理を繰り返す．ここで，Web ゚゚ージのオフライン情報と は，Web ページに関して検索エンジンから得られたヒッ トリストから得た情報であり，獲得は高速であるが，一 般に鮮度が低い [Menczer 99]. これに対し，オンライン 情報とは，ページ情報ェージェントが実際に光のページ を持つWeb サーバに接続して，HTML ファイル，ヘッ 名等を獲得して，乥こからタグ構造などを参考に抽出し た情報であり，鮮度は高いが , ネットワークトラフィック の影響などにより獲得には時間がかかる .この 2 つの情 報のどちらがユーザにとって有益かは一概に決まらない ため，AOAIでは両方を用意している．AOAIの一回の検 索手続きの詳細を以下にまとめる .

(1) AOAIに，検索したいクェリを入力し，光の結果 のヒットリストを得る .

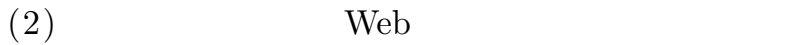
各インタフェースェージェントが自分の情報を獲得 する．各ェージェントは，JAVA のスレッドに割り
当てられ，疑似並列的に実行される.なお，エージェ ントにより，オンライン情報，またはオフライン情 報を調べる 。

(3) ユーザインタフェースウインドウ (図 2) が提示 さる.ユーザは, 弚れを基に以下の処理により目標 ページを探す．

a ユーザがページ情報の欲しい Web ページの Web ページ番号上にカーソルを移動させると， 光のページのページ情報を各ェージェントは吹 き出しを使って 1 つずつ提供する

b ページ情報ェージェントの提示するページ情 報を見ながら，適切な Web ページを決定して， 弚の Web ページ番号アイコンをクリックする と, Web ブラウザが開き, 弚のページが表示さ れる.

c ユーザは, ブラウザの表示したページを見て， 弚れが目標ページなら，Exitボタンを押す。目 標ページでないなら， $3 \mathrm{~b} へ$ 。

（4）ページ情報エージェントの成長及び組織化が行わ れ，検索は終了する .

また , ユーザは, (3) の任意のタイミングで, 以下を実 行可能である . 


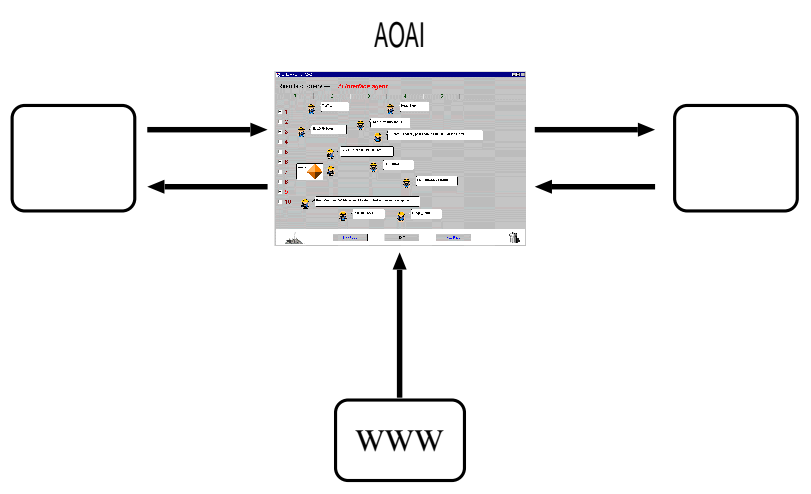

図 3 AOAl の概要図

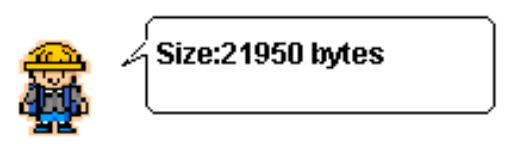

図 4 吹き出しを持つページ情報エージェント

・エージェントの評価：ページ情報エージェントを評 価できる.ユーザは, ページ選択にとって有用であっ たエージェントを右クリックすることにより，㫕の 評価値を増加させる．また，役に立たなかったエー ジェントを中クリックすることにより, 評価値を減 少させる.これらのクリック数に制限はなく, ユー ザは好きなタイミングで好きな回数だけクリックし てよい.

・直接操作によるエージェントの配置: ユーザは, 各 エージェントをドラッグ\&ドロップし，弚れ攵れ提 示する情報が見やすいようにエージェントを配置す ることができる

- 直接操作によるエージェントの分解と再生: エージェ ントは統合と分解が可能であるが, 兴の分解は, ユー ザが統合されたエージェントを解体工場アイコンに ドラッグ\&ドロップすることにより実現される．ま た,ゴミ箱には, 評価により消滅したエージェント が格納されており，ユーザはゴミ箱アイコンをダブ ルクリックで開き，適当なエージェントをゴミ箱外 にドラッグ\&ドロップすることにより，再生するこ とができる .

\section{3. ページ情報エージェント}

AOAIでは, 複数のページ情報エージェントと呼ばれ るプログラムが , ページ情報をユーザに提示する .この ページ情報エージェントは, ユーザにシステム側の持って いる情報を提示するという意味で，インタフェースェー ジェント [Maes 94] の一種である .すべてのエージェン 卜は, 図 4 のように, 弚の吹き出し中にページ情報を表 示する .
さらに，すべてのページ情報を表形式で表示し，使用 する属性のオンオフをユーザが選択する方法等では実現 できないAOAI の機能として，以下のものが考えられる .

・列をページ情報，行をWebページとした表形式では， ページ情報は 1 次元の位置関係として扱かわれるの で，全順序関係て評価される。弚れに対し，AOAIで は, エージェントは， 2 次元平面に配置されるため， 半順序関係の評価に対応でき,より柔軟な評価が可 能である。

・エージェントのキャラクタを表示することにより， ユーザに対し単なる表よりもより注視を促すことが 可能である [André 98] .

・子供から大人に変化するキャラクタ表示により,エー ジェントの評価が非常に直観的に把握できる．表形 式でも , 図形の大小 , 色などにより, 評価を表現可能 であるが，キャラクタの方がより直観的であり，説 明がなくとも解釈が一意に決まる .

初期状態では,一つのエージェントは,一種類のページ 情報を吹き出し中に表示し，後に複数のエージェントがー つに統合されると光れらのエージェントの表示情報がま とめて提示される . AOAIでは，以下に示す 12 個のエー ジェントを用意している . 同じ意味のラベルで , “_Now” がついているものは，オンライン情報を意味する．

URL エージェント：オフライン情報である，Webペー ジの URL を表示する .

Traffic エージェント：オンライン情報である，Web ページのサイトへのネットワーク負荷を表す, "Light" , "Heavy", "Server down"を表示する.

Title エージェント：オフライン情報のページタイト ルを表示する .

Title_Now エージェント：オンライン情報のページ タイトルを表示する .

Head エージェント：オフライン情報である，Web ページの最初の数単語を表示する.

Head_Now エージェント： オンラインでページを獲 得し，タグを取り除いて最初の数単語を表示する.

Precision エージェント：オフライン情報である,検 索エンジンが算出したスコア $(\%)$ を表示する

Size エージェント：オフライン情報である, Webペー ジの容量を表示する .

Size_Now エージェント： Webページのヘッタ情報 をWeb サーバからオンラインで取得し，ページの 容量を表示する．ヘッ㕛情報に容量がない場合は， “UnKnown”を,ヘッダが返ってこない場合は “Not Found”を表示.

LMD_Now エージェント： オンラインでヘッダ情 報を取得し，光のページの最終更新日を表示する． Size_Now エージェントと同樣に , “UnKnown" と "Not Found"も表示する .

Image_Name エージェント： Web ページが画像フ 


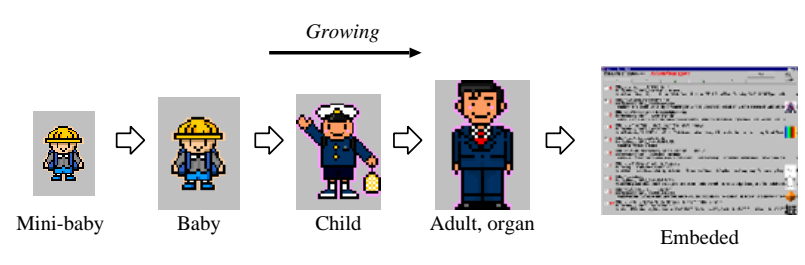

図 5 各ランクのキャラクタ

アイルへのリンクをもつ場合 , 弚のファイル名 , 属 性を表示する .これは，HTML ファイルを解析して 得られるオンライン情報である .

Image エージェント： Image_name エージェントの 解析結果と URL から画像ファイルをオンラインで 取得して表示する。

このようなエージェントの中には, 一見あまり重要で はない情報を提示していると思われるかもしれないが， 弚れは本システムにおいては重要な問題ではない．なぜ なら，弚の情報が必要か否かはユーザが判断し，不要な エージェントは消去されていくからである．つまり，シ ステム側はユーザの選択範囲が広がるように十分な種類 のエージェントを設計することが重要である .

\section{4. ページ情報エージェントの組織化}

\section{$4 \cdot 1$ エージェントの属性}

ページ情報ェージェント $A_{i}$ は，組織化や兰れ自体の 振る舞いのために，次のような属性を持っている．

・成長度 $G_{i}$ : この值は, エージェント $A_{i}$ に対するユー ザの評価を表し，下式で計算される.いずれの評価 回数も，過去 10 回の検索におけるマウスクリック回 数である.このように制約することにより，ユーザ の興味か変化した場合にも追従可能になる。

$$
G_{i}=(\text { 正の評価回数 })-(\text { 負の評価値回数 })
$$

・ランク $R_{i}$ : エージェントのランクは, 成長度 $G_{i}$ に応 じて ,trash, mini-baby, baby, child, adult, organ, embedded の 7 つの值をとる . 各ェージェントのラ ンクの初期值は, baby であり，ユーザの評価により， child, adult, organ に成長, あるいは, mini-baby に衰退し，弚の後エージェントの統合を繰り返した 結果 , 最終的に一つになったエージェントは UIWに 埋め込まれ，弚のランクは embedded となる.ゴミ 箱に捨てられたエージェントのランクが, trash で ある.なお，エージェントは，ランクに対応した図 5 のようなキャラクタを持っている

・ページ情報 $I_{i}$ : エージェント $A_{i}$ が表示する情報の リストである

- 位置 $P_{i}(x, y): \mathrm{UIW}$ 上でのエージェント $A_{i}$ の 2 次 元座標である . この值は, $A_{i}$ と $A_{j}$ の間の距離 $D_{i j}$ を計算するために使用される .

\section{$4 \cdot 2$ 個々のエージェントの成長}

$\mathrm{AOAI}$ は, 成長閾值 $\psi_{G}\left(R_{i}, R_{j}\right)$ と衰退閾值 $\psi_{E}\left(R_{j}, R_{i}\right)$ により組織化を制御する. 基本的には, ランク $R_{i}$ のエー ジェントの成長度 $G$ が $\psi_{G}\left(R_{i}, R_{j}\right)$ 以上になったとき， ランクが一つ上の $R_{j}$ となり， $G=0$ でリセットされ る。また，逆に，ランク $R_{j}$ のエージェントの成長度 $G$ が $\psi_{E}\left(R_{j}, R_{i}\right)$ 以下になったとき, 弚のランクが一っ下 の $R_{i}$ となり， $G=0$ でリセットされる.ただし ,ランクが mini-babyのエージェントの $G$ が $\psi_{E}($ mini-baby, trash $)$ 以下になった場合, 弚のエージェントはゴミ箱に入れら れる．また，埋め込みについては，後述する別処理が行 われる。

\section{$4 \cdot 3$ ページ情報エージェントの統合}

AOAIでは, 個々のエージェントの成長度と, エージェ ント間の距離に基づき統合が行われる .これは, 近くに 配置したエージェント同士は, 統合した方が見やすいと いうことをユーザが示唆していると考えられるためであ る.まず, 2 つのエージェント $A_{i}$ と $A_{j}$ 間で, 下式の条 件か調べられる.ここで, $D_{i j}$ は, $A_{i}$ と $A_{j}$ 間の最近 10 回の検索における距離の平均である .この式は, 2 つの エージェント間の距離 $D_{i j}$ が $\psi_{D}$ より小さく，かつ両方 のランクが organ であるという意味である .

$$
\left(D_{i j}<\psi_{D}\right) \wedge\left(R_{i}=\text { organ }\right) \wedge\left(R_{j}=\text { organ }\right)
$$

次に, 上式の条件が満たされたすべてのエージェント をノードとして，光のペアの間にアークを貼った無向グ ラフを考える．乥して，弚のグラフにおける極大連結グ ラフのノードの集合を一つのグループとしてェージェン 卜の統合を行う.極大クリークでは, 完全グラフである必 要があり，統合されにくくなるため，より条件の緩い極大 連結グラフを用いた . また , 極大連結グラフを取り出すた めに縦型探索を行うが, 計算コストは $O(n)(n:$ エージェ ントの個数) で, 弚の操作は十分に速い．統合が行われ た後，エージェント $A_{i}, \cdots, A_{j}$ か統合された新しいェー ジェント $A_{k}$ の $I_{k}$ と $G_{k}$ は，弚れ光れ $I_{k}=I_{i} \cup \cdots \cup I_{j}$, $G_{k}=0$ となる.

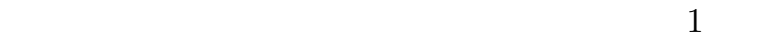
エージェントに統合されたときに，兴のエージェントがも つページ情報はテキストとして，UIWに埋め込まれる．

\section{$4 \cdot 4$ 実 行 例}

図 6 は, AOAI の初期画面 (図 2) から, 各エージェン 卜が成長した画面を示している．図７にインタフェース エージェントの統合結果を示す.ここで, 图 6 の左下の 3 つのエージェントと右上の 2 つのエージェントは, 弚れ 光れランクが organ であり，かつ距離が十分近いことか

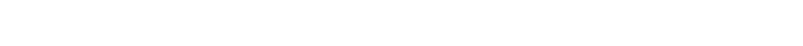
プに統合され，表示結果にも反映されている． 


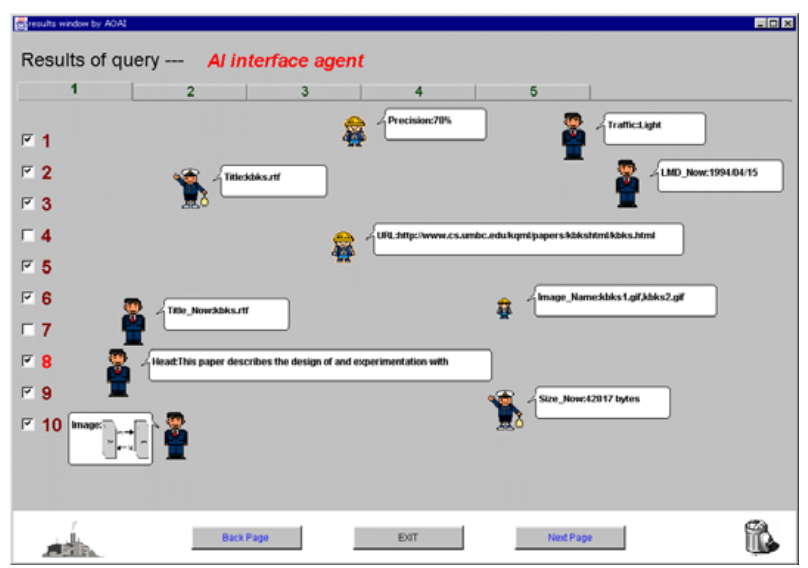

図 6 各ェージェントの成長

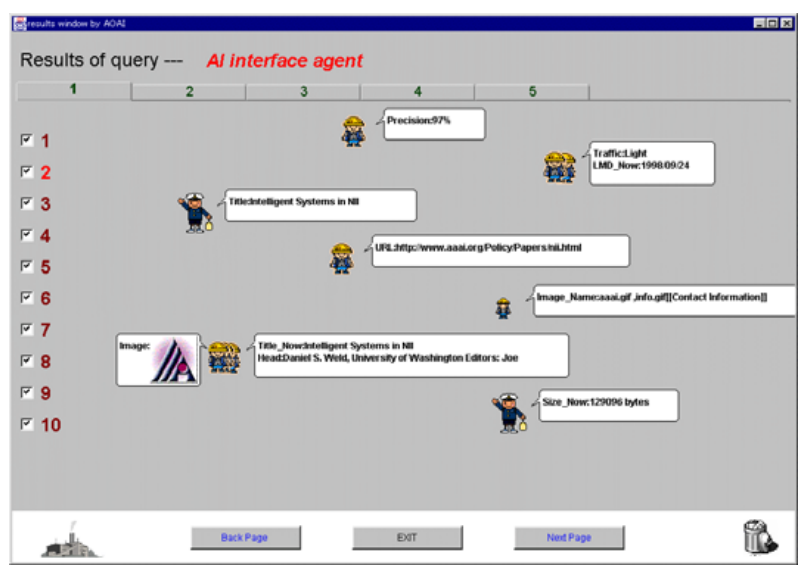

図 7 エージェントの統合

このように使用頻度の低いェージェントは消去されて いき, 使用頻度の高く, 距離が近いェージェントどうし は統合される．乥してェージェントが1つに組織化され た時，図 8 のように埋め込みが行われる。ここでは，5 つのエージェントが 1 つに統合され，ヒットリストに光 れらの表示するページ情報が埋め込まれた状態である .

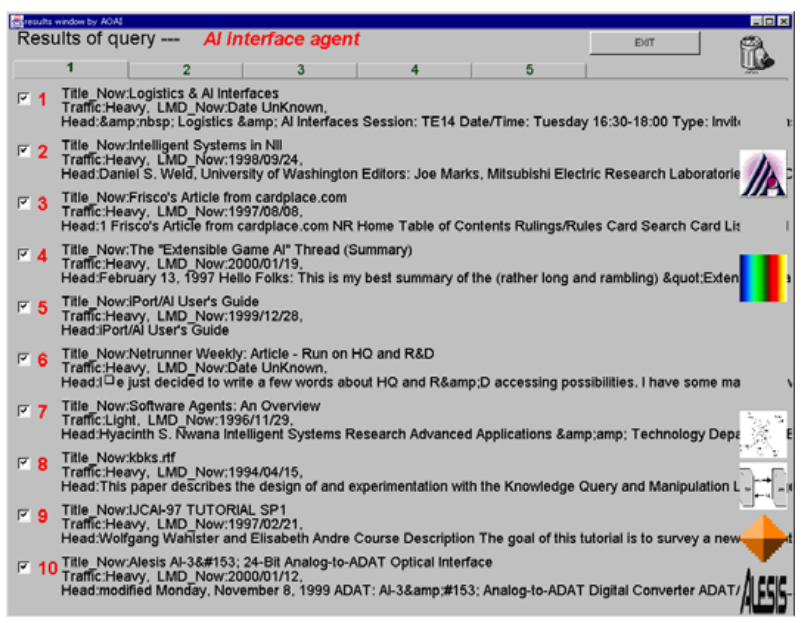

図 8 最終埋め込み画面

\section{5. 評 価 実 験}

AOAl がページ情報エージェントを組織化することの 価値を示し，また検索エンジンとの比較実験を行うこと により，本システムの有効性を示すため，被験者による $3 つ$ 実験を行った .実験 1 では，被験者にAOAI を自由 に使用してもらい，ユーザによって適切なページ情報が 異なることを示す．実験 2 では，検索キーワード分野の 変化に対して，AOAIがどのように追従するかを調べる． 最後に, 実験 3 では, 本システムと従来の検索エンジン との比較実験することで, 本システムの優位性を示す .

以下のすべての実験における被験者は, 理工系大学院 の教員 1 名と修士課程の学生であり，事前に実験の目的等 の実験結果に支障をきたすことは伝えていない，ただし， "XX_Now" と表示のあるのは, オンライン情報であるこ と，乥してオンライン情報の意味は被験者に事前に伝え た．また，AOAI が使う検索エンジンは，大規模なもの としては比較的レスポンスのよいInfoseek を用いた .な お，全実験を通して，成長閾値は， $\psi_{G}($ mini-baby, baby) $=1, \psi_{G}($ baby, child $)=5, \psi_{G}($ child, adult $)=10$, $\psi_{G}($ adult, organ $)=15$, 衰退閾值は, $\psi_{E}($ organ, adult $)$ $=-15, \psi_{E}($ adult, child $)=-10, \psi_{E}($ child, baby $)=$ $-5, \psi_{E}($ baby, mini-baby $)=-1, \psi_{E}($ mini-baby, trash $)$ $=-5$, 乥して, ェージェント間距離の閾値は, $\psi_{D}=$ 200(pixel) と設定した . UIW の大きさは, 1000 (pixel) × 780 (pixel) である.

\section{$5 \cdot 1$ 実験 1：ページ情報のユーザ依存性}

もし適切なページ情報がどのユーザでも同じであるな ら，光のページ情報を事前に調ベてインタフェースを設 計すればよく，AOAIのようにユーザやタスクに対し適応 的にインタフェースを構築する必要はない，弚こで，実 験 1 として , 適切なページ情報がユーザに依存するかど うかを調べた .具体的には, 9 名の被験者に, エージェ ントが埋め込み状態になるまで, 自由にAOAI を使って もらい，埋め込まれたエージェントを調べた .

埋め込み状態まで残ったエージェントを，表 1 に示す． 埋め込み状態までの平均検索回数と弚の標準偏差は, 9.0 回と 3.4 回であった . また, 1 検索あたりの平均時間と 谷の標準偏差は, 165 秒と 92 秒であつた . また，埋め込 まれたエージェントの累積を図 9 に示す.

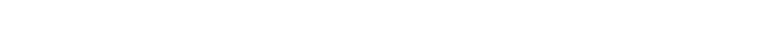
れ光れ URL: URL エージェント $, \operatorname{Tr}: \operatorname{Traffic}$ エージェン 卜, T1 : Title エージェント, T2 : Title_Now エージェン 卜 , H1 : Head エージェント , H2 : Head_Now エージェン ト, S1 : Size エージェント , S2 : Size_Now エージェント , Pr : Precision エージェント , LMD : LMD_Now エージェ ント, I1 : Image_Name エージェント, I2 : Image エー ジェントを表している .

表 1 から，Webページ検索において必要としている情 
表 1 実験 1 の結果

\begin{tabular}{|c|c|}
\hline 被験者 & 埋め込まれたエージェント \\
\hline A & URL,Tr,T1,H2,LMD,I2 \\
B & URL,T1,H1,Pr,LMD,I2 \\
C & Tr,T1,T2,LMD,I1,I2 \\
D & $\mathrm{URL}, \mathrm{T} 2, \mathrm{H} 2, \mathrm{Pr}, \mathrm{I} 2$ \\
E & $\mathrm{Tr}, \mathrm{T} 2, \mathrm{H} 2, \mathrm{Pr}, \mathrm{I} 2$ \\
F & $\mathrm{URL}, \mathrm{T} 1, \mathrm{~T} 2, \mathrm{H} 1, \mathrm{H} 2, \mathrm{I} 2$ \\
$\mathrm{G}$ & $\mathrm{T} 1, \mathrm{~T} 2, \mathrm{H} 1, \mathrm{H} 2$ \\
$\mathrm{H}$ & $\mathrm{URL}, \mathrm{Tr}, \mathrm{T} 1, \mathrm{~T} 2, \mathrm{H} 1, \mathrm{LMD}, \mathrm{I} 1, \mathrm{I} 2$ \\
$\mathrm{I}$ & $\mathrm{URL}, \mathrm{T} 1, \mathrm{~T} 2, \mathrm{Pr}, \mathrm{I} 2$ \\
\hline
\end{tabular}

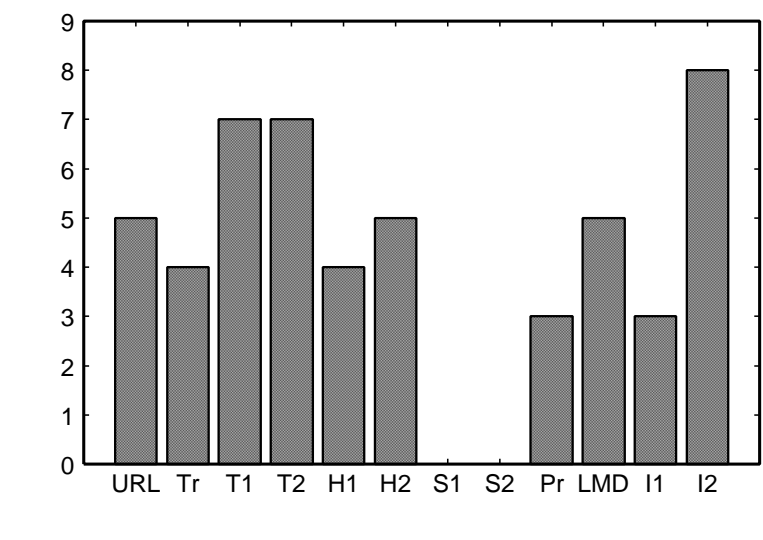

図 9 埋め込まれたエージェントの累積

報はユーザによって大きな違いがあることがわかる．ま た，図 9 から，すべてのユーザが必要とするページ情報 は, 1 つもなかったことがわかった . 特に , ほとんどの 検索エンジンがヒットリストに提示しているページ情報 であるファイル容量を表示する Size , Size_Now エージェ ントに関しては, 今回のすべての被験者が必要としてい ないことは注目に値する .

また , オンラインとオフラインの両方があるページ情 報 Title, Head, Size について，どちらの情報が埋め込 みまで残ったを調べた，乥の結果は，オンライン情報が 21 , オフライン情報が 13 であり，表示に時間を要する にも関わらず，オンライン情報が多く使われていること がわかる .

以上の実験 1 の結果から，ユーザに応じて提示するペー シ情報を選択することは，有効であると考えられる．

\section{$5 \cdot 2$ 実験 2：クエリ分野の変化}

本実験では,クエリが属する分野 (クエリ分野) か変 化した場合に，ユーザは，AOAl を通して適切なページ 情報を適応的に追従させることができることを確認する． 4 つのクエリ分野から 1 人 3 分野ずつ選択して, 実験 1 のテキスト埋め込み状態から始めて, 自由な順序で各ク エリ分野の検索をしてもらう. 分野が変化した際に，ゴ ミ箱の中に必要なエージェントがあればとれを取り出し，

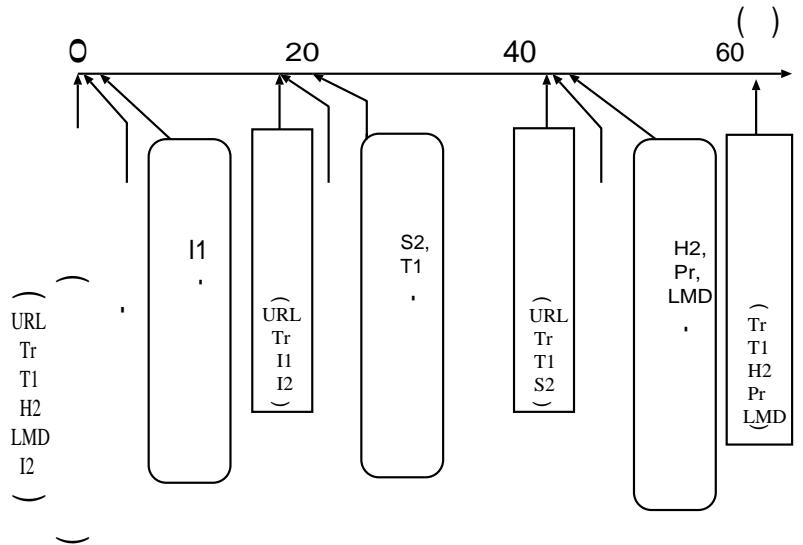

図 10 実験 2 の典型例

再度埋め込み画面になると 1 分野の終了とし，次のクェ リ分野に移る、また, 数回検索行った後, ゴミ箱中に必 要なエージェントがないと試験者が判断した場合も，光 のクエリ分野は終了とする.4つのクェリ分野として , 以 下のものを用意した .

・Program : プログラミングテクニック関係分野

-Paper : 文献関係分野

- Present : 懸賞関係分野

- Image : 画像関係分野

被験者 4 名で, 合計 12 のクエリ分野の変更を行った結 果, 11 のクエリ分野変更に対して, 埋め込み状態からゴ ミ箱中のエージェントの再生, さらに再埋め込みという 状態遷移が見られ, ユーザがAOAI を通して, クエリ分 野の変化に対して適切なページ情報を適応的に追従させ ていることが確認された . また, クエリ分野か変化した 際に，埋め込み状態が解消され次の埋め込み状態になる までの平均検索回数は 6.6 回であつた . 典型的な結果を， 图 10 に示す.クェリ分野の変化に伴い, インタフェース エージェントが再組織化されていることがわかる .

なお，本実験の結果において，同じクェリ分野で使わ れるェージェントが, 必ずしもユーザ間で共通している わけではない．この実験結果で我々が主張したいことは， 「ユーザの検索意図か変化したときに, ユーザがェージェ ントを操作することにより，光の変化に対応できる枠組 みを AOAI は提供できる」ことである.よって，埋め込 まれるェージェントに共通性がないことは, 我々の主張 を否定するものではない .

\section{$5 \cdot 3$ 実験 $3:$ 検索エンジンとの比較}

AOAI の埋め込み状態と検索エンジンの検索性能を比 較評価する . 比較対象の検索エンジンは, 主要な検索エ ンジンの一つであり，AOAI でも使われている Infoseek を用いた . 被験者は, 実験 2 の 4 つのクエリ分野の中か ら 1 つを選択し，弚の分野に即したクエリを被験者が選 んで検索を行う.AOAI は, 弚の分野で埋め込み状態に 
表 21 試行あたりの平均時間 $[\mathrm{sec}]$ と実際に調ベたページ数

\begin{tabular}{|c|cc|cc|}
\hline & \multicolumn{2}{|c|}{ 平均時間 [sec] } & \multicolumn{2}{c|}{ 調ベたページ数 } \\
\hline 分野 & AOAI & Infoseek & AOAI & Infoseek \\
\hline program & 261 & 475 & 4.4 & 13.4 \\
paper & 219 & 330 & 2.6 & 11.8 \\
present & 551 & 546 & 5.9 & 5.5 \\
image & 207 & 381 & 1.7 & 9.8 \\
\hline 全体 & 298 & 411 & 3.4 & 9.1 \\
\hline
\end{tabular}

なったヒットリストを用いて実験を行う．また，インタ フェースの効果を評価したいので, Web ページのリンク はたどらないとする．㫕して，適合する Web ページを 一つ見つけるまでを 1 試行とし , クエリを変えて計 4 試 行ずつ実験をする .

被験者 9 名で, 乥の内 program, paper, presentの分 野において 2 人ずつ, image には 3 人の被験者で実験を 行った . 実験結果として，AOAI と検索エンジンの 1 試 行あたりの平均時間と, 実際に調べられた Web ページ 数の平均を表 2 に示す.

表 2 から，1 試行あたりの平均時間は, AOAI の方が 短いが, $t$-検定（危険率 $5 \%$ ）を行った結果，有意差はな かった・しかし, 調べたページ数については, クェリ分野 全体の平均で, AOAI の方が半分以下になっており，この 差は $t$-検定 (危険率 $5 \%$ ) で有意であった . ユーザにとっ て，ヒットリスト中の Web ページを実際に取ってきて， 弚れが求めるページであるかを調べる作業は, 大きな負 荷となるため, 時間が検索エンジンとほぼ同じで, かつ 調べるページ数は検索エンジンの半分以下であるAOAI は , 検索エンジンよりも優れていると言える .

ただし，この実験は, クエリ分野に依存した評価であ る．つまり，あるクエリ分野で得られた埋め込み状態は， そのクエリ分野においては, 検索エンジンよりも調べる ページ数が少なくてすむということであり，クエリ分野 に依存せずに一般的に有効な埋め込み状態が得られたわ けではない .このことは, 先の実験 2 からもわかるよう に, AOAI がクェリ分野に依存したインタフェースを構 成することから，当然の結果と考えられる。

\section{6. ま と め}

本論文では, 検索エンジンのヒットリストにおけるペー ジ情報を表示するマルチページ情報エージェントを, ユー ザか評価し，また直接操作により適切に配置することに より, 徐々にェージェントの統合が行われ, 最終的には ユーザにとって適切なページ情報のみを表示するヒットリ ストを構成できる適応インタフェースAOAI を提案した． また，被験者による実験を行い，ユーザによって，あるは タスクによって, 適切なページ情報が異なること，AOAI によりページ情報の埋め込まれたヒットリストと検索エ ンジンの比較実験により，AOAI の優位性を示した．
謝辞

本研究は, 日本学術振興会 未来開拓学術研究推進事業 研究プロジェクト「生物的適応システム」の支援のもと に行なわれました．記して，感謝いたします．

\section{$\diamond$ 参 考 文 献 $\diamond$}

[André 98] André, E., Rist, T., and Müller, J.: Guiding The User Through Dynamically Generated Hypermedia Presentations with a Life-Like Character, in 1998 International Conference on Intelligent User Interfaces, pp. 21-28 (1998).

[Cypher 91] Cypher, A.: Eager: Programming Repetitive Tasks By Example, in Proceedings of the ACM Conference on Human Factors in Computing Systems, pp. 33-39 (1991).

[Dryer 97] Dryer, D. C.: Wizards, guides, and beyond: rational and empirical methods for selecting optimal intelligent user interface agents, in Proceedings of the 1997 International Conference on Intelligent User Interfaces, pp. 265268 (1997)

[Joachims 97] Joachims, T., Freitag, D., and Mitchell, T.: WebWatcher: A Tour Guide for the World Wide Web, in Proceedings of the Fifteenth International Joint Conference on Artificial Intelligence, pp. 770-775 (1997).

[Khme 93] Khme, T.: A user-centered approach to adaptive interfaces, in Proceedings of the International Workshop on Intelligent User Interfaces, pp. 243-245 (1993).

[Lieberman 95] Lieberman, H.: Letizia: A agent that assists Web Browsing, in Proceedings of the Fourteenth International Joint Conference on Artificial Intelligence, pp. 924929 (1995).

[Maes 94] Maes, P.: Agents that Reduce Work and Information Overload, Communications of the ACM, Vol. 37, No. 7, pp. 30-40 (1994).

[Masui 94] Masui, T. and Nakayama, K.: Repeat and Predict - Two Keys to Efficient Text Editing, in Proceedings of the ACM Conference on Human Factors in Computing Systems (CHI'94), pp. 118-123 (1994).

[Menczer 99] Menczer, F. and Monge, A. E.: Scalable Web Search by Adaptive Online Agents: An InforSpiders Case Study, in Intelligent Information Agents, pp. 323-347, Springer (1999).

[Norcio 89] Norcio, A. F. and Stanley, J.: Adaptive HumanComputer Interfaces: A Literature Survey and Perspective, IEEE Transaction on Systems, Man, and Cybernetics, Vol. 19, No. 2, pp. 399-408 (1989).

[Pandit 97] Pandit, M. S. and Kalbag, S.: The Slection Recognition Agent: Instant Access to Relevant Information and Operations, in Proceedings of the 1997 International Conference on Intelligent User Interfaces, pp. 47-52 (1997).

[Thomas 93] Thomas, C. G. and Krogster, M.: An adaptive environment for the user interface of Excel, in Proceedings of the International Workshop on Intelligent User Interfaces, pp. 123-130 (1993).

〔担当委員 : 國藤 進〕

2000 年 3 月 27 日 受理 


\section{著 者 紹 介}

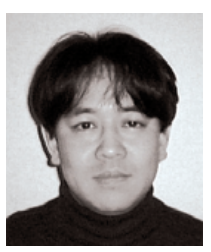

山田 誠二(正会員)

1984 年大阪大学基礎工学部卒業. 1989 年同大学院博士

課程修了, 博士 (工学) , 同年大阪大学基礎工学部助手.

1991 年同大学産業科学研究所講師. 1996 年東京工業大 学大学院総合理工学研究科助教授, 現在にいたる. 人工知

能，特に，Webでの情報收集，ロボット学習に興味をも

つ. 情報処理学会, 日本ロボット学会, 電子情報通信学会,

AAAI, IEEE, ACM 各会員.

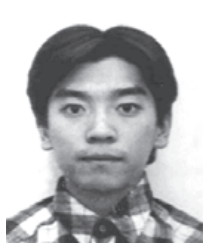

\section{村瀬 文彦(学生会員)}

1998 年東京工業大学工学部制御システム工学科卒業 . 2000 年同大学大学院総合理工学研究科修士課程在修了. 現在, （株）デンソーに勤務 